\title{
Changes in Maternal Serum Leptin Levels during Pregnancy and after Labor in Preeclampsia, and Its Correlation to Neonatal Cord Leptin
}

\author{
Mohamed Abdelaziz Youssry ${ }^{1 *}$, Mohamed Amin Gabreel ${ }^{2}$, Tabarak Ahmed Patel ${ }^{3}$ \\ ${ }^{1}$ Obstetrics and Gynecology Department, Faculty of medicine, Alexandria University, Alexandria, Egypt \\ ${ }^{2}$ Pediatrics Department, Faculty of medicine, Al Azhar University, Cairo, Egypt \\ ${ }^{3}$ Clinical Pathology Department, IBN SINA College Hospital, Jeddah, Saudi Arabia \\ Email: *dr_youssry@yahoo.com
}

How to cite this paper: Youssry, M.A., Gabreel, M.A. and Patel, T.A. (2016) Changes in Maternal Serum Leptin Levels during Pregnancy and after Labor in Preeclampsia, and Its Correlation to Neonatal Cord Leptin. Open Journal of Obstetrics and Gynecology, 6, 588-600.

http://dx.doi.org/10.4236/ojog.2016.610074

Received: July 30, 2016

Accepted: August 27, 2016

Published: August 30, 2016

Copyright $\odot 2016$ by authors and Scientific Research Publishing Inc. This work is licensed under the Creative Commons Attribution International License (CC BY 4.0).

http://creativecommons.org/licenses/by/4.0/ (c) (i) Open Access

\begin{abstract}
Objective: The aim of this study is to determine changes in maternal serum leptin level during pregnancy and after labor in preeclamptic patients compared to healthy pregnant women. Furthermore, to investigate whether maternal serum leptin levels are correlated to the clinical characteristics and laboratory parameters of the study participants, and the possible correlation between maternal and neonatal leptin levels. Subjects and Methods: In this case control study, a total number of fifty five pregnant women in third trimester of pregnancy ( $\geq 28$ weeks) were recruited. All of them were of the same age, body mass index, and gestational age. After a detailed obstetrical and medical history, they were divided into 2 groups. Group (A) 30 pregnant women with preeclampsia, and Group (B) 25 normotensive pregnant women. Results: During pregnancy, maternal serum leptin levels were significantly higher $41.0 \pm 9.78 \mathrm{ng} / \mathrm{ml}$ in preeclamptic group compared to control group $24.6 \pm 3.64 \mathrm{ng} / \mathrm{ml}(\mathrm{p}=0.007)$. After labor, it decreased significantly in both groups to $15.3 \pm 3.19$, and $11.2 \pm 2.68 \mathrm{ng} / \mathrm{ml}$ respectively ( $\mathrm{p}=0.001,0.002)$. In group $(\mathrm{A})$ there were significant positive correlations between maternal serum leptin and diastolic blood pressure $(r=0.419, P=0.021)$, total cholesterol $(r=0.383, P=0.026)$, and uric acid $(r=0.424, P=0.012)$ compared to controls, and no significant correlations were found between maternal serum leptin and body mass index, neonatal birth weight or cord leptin level in both groups. Conclusion: Maternal serum leptin is significantly increased in preeclamptic patients compared with normal pregnant women independent of body mass index. There is strong evidence that placenta, rather than maternal adipose tissue is responsible for that. In addition, maternal serum leptin levels were found to correlate positively with diastolic blood pressure, uric acid, and total cholesterol, but not correlated with body mass index, cord blood leptin and birth weight.
\end{abstract}




\section{Keywords}

Preeclampsia, Body Mass Index, Leptin

\section{Introduction}

Leptin is a homeostatic hormone, produced by the obesity $\left(\operatorname{Lep}^{\phi}\right)$ gene on chromosome 7 , synthesized and secreted by adipocytes [1] [2], and other organs particularly the placenta which may contribute to leptin levels during pregnancy [2] [3].

This anti-obesity hormone mainly acts by binding to specific central and peripheral receptors in the hypothalamus, adipose tissue, liver and pancreatic beta cells. Leptin stimulates a negative energy balance by increasing energy expenditure and reducing food intake thus controlling body weight [4]. It also modulates glucose metabolism via increasing insulin sensitivity, activates the sympathetic nervous system, and it has been implicated in the control of the reproductive functions particularly embryonic development [5]. Furthermore, leptin is involved in the regulation of immune responses and inflammations [6], since it is considered as a pro-inflammatory cytokine that belongs to the type I cytokine superfamily [7].

However, the regulation of maternal leptin during pregnancy is difficult [8]. Serum leptin concentrations double during the course of a normal pregnancy and decrease just before labor [9]. Trophoblasts are obligated for the considerably increased leptin levels during the first two trimesters of normal pregnancies [1], subsequently necessary substrates for placental and fetal growth are provided by mobilizing maternal fat stores [8]. Fluctuation of leptin levels in pregnancy correlates with estradiol and human chorionic gonadotropin (HCG) levels in maternal circulation. This situation suggests that there is a dynamic relation between fluctuating levels of reproductive hormones oscillated in pregnancy and leptin [9].

Moreover, another important source of leptin could be fetal adiposity, and fetal leptin levels are strongly correlated to birth weight [10]. However, leptin receptors possibly are participating in the endocrine control of human pregnancy; these receptors are abundant in the uterine endometrium, trophoblast, and the fetus [11]. Leptin levels show further increase in complicated pregnancies as preeclampsia, and intrauterine growth restriction (IUGR) [12] [13]. In such conditions there is reduction in placental circulation, therefore leptin acts as a gestational hormone for regulation of placental and fetal growth, and could be a marker for severity of preeclampsia and IUGR [14].

Preeclampsia refers to the new onset of hypertension and either proteinuria or end organ dysfunction after 20 weeks of gestation in a previously healthy woman [15]. It is one of the major causes of maternal and perinatal morbidity and mortality [16]. The etiology and pathogenesis are not completely understood, but the overproduction of cytokines, and chemokines may trigger a generalized endothelial dysfunction which is characteristic of preeclampsia [17]. In addition to angiogenic and anti-angiogenic imbalance which has also been implicated in the development of disease [18]. Adipose 
tissue also acts as endocrine tissue producing a wide range of cytokines and chemokines such as leptin, which play a role in normal pregnancy, as well as in preeclampsia [19]. More specifically, it has not yet been established whether leptin levels are simply a marker of fat mobilization, or whether there is a disrupted relationship between the serum leptin and adiposity in preeclampsia [20].

Several studies demonstrated that serum leptin levels increase in preeclamptic patients [19] [21] [22], while others showed unchanged or decreased leptin levels [23] [24]. Over expression of leptin gene was demonstrated in preeclamptic women compared with normal pregnancies [25]. Although there is placental hypoperfusion in preeclampsia, only one-third of neonates born have IUGR due to increased availability of nutrients in placenta [26].

This aim of this study is to determine changes in maternal serum leptin level during pregnancy and after labor in preeclamptic patients compared to healthy pregnant women. Furthermore, to investigate whether maternal serum leptin levels are correlated to the clinical characteristics and laboratory parameters of the study participants, and the possible correlation between maternal and neonatal leptin levels.

\section{Subjects and Methods}

This case control study was conducted at the Department of Obstetrics and Gynecology of Ibn Sina College General Hospital, Saudi Arabia, from November 2014 till April 2016. A total number of fifty five pregnant women attending in the third trimester of pregnancy ( $\geq 28$ weeks) were recruited in the study.

This study was approved by the Hospital Research Ethics Committee and has been performed in accordance with the ethical standards as in Declaration of Helsinki (1964) and its later amendments, and a written informed consent was obtained from each participant. All participants were of the same age, body mass index, and gestational age. They were briefed about the nature of the study, and after a detailed obstetrical and medical history, they were divided into 2 groups. Group (A) 30 pregnant women with preeclampsia, and Group (B) 25 normotensive pregnant women.

Preeclampsia refers to the new onset of hypertension (systolic blood pressure $\geq 140$ $\mathrm{mmHg}$ or diastolic blood pressure $\geq 90 \mathrm{mmHg}$ on two occasions four hours apart and proteinuria $\geq 300 \mathrm{mg}$ in a $24 \mathrm{~h}$ urine collection or at least on dipstick measurements $\geq+1$, or new onset of end organ dysfunction in the absence of proteinuria (American College Of Obstetrics and Gynecology 2013) [15]. Blood pressure was measured with the arm at the level of the heart using an appropriately sized cuff (length of 1.5 times the circumference of the arm) with a mercury sphygmomanometer after 10 minutes rest period.

Inclusion criteria

Group (A): Thirty preeclamptic women with singleton pregnancies in their third trimester.

Group (B): Twenty five normal healthy women with singleton pregnancies in their third trimester as controls.

Exclusion criteria 
- Pre-existing chronic hypertension.

- Gestational diabetes or Pre-existing diabetes.

- Peripheral vascular disease.

- Chronic renal or liver disease.

- Multiple pregnancies.

- Antihypertensive medications.

Maternal fasting blood samples were obtained from the antecubital vein from all subjects at antenatal visit after the preeclampsia diagnosis was confirmed for group (A), and controls for group (B). Complete blood count, complete urine analysis, urea, creatinine, uric acid, aspartate aminotransferase (AST), alanine aminotransferase (ALT), total cholesterol, triglycerides, and serum leptin were measured. In the post-partum stage, during the first 24 hours after labor another blood sample was taken from all the pregnant women from antecubital region for serum leptin. Umbilical vein samples were taken immediately following clamping of the cord before separation of the placenta, then serum was separated and serum leptin level was measured. In addition to neonatal weights, head circumference, and other measurements.

The blood samples were collected under strict aseptic measures. Each sample was labeled with patient's name and identification number. Serum Leptin levels were measured by enzyme-linked immunosorbent assay (ELISA) method using DRG leptin (Sandwich) ELISA Kit (EIA-2395) purchased from DRG instruments (GmbH, Germany) following the manufacturer's recommendations.

\section{Statistical Analysis}

The data was collected and entered into the personal computer. Statistical analysis was done using Statistical Package for Social Sciences (SPSS/version 20) software. Arithmetic mean, standard deviation, for categorized variables Chi-square test was used, while for numerical data t-test was used to compare two groups. The correlation was analyzed by Spearman correlation coefficients. The level of significance was 0.05 .

Sample size calculation: A minimum two groups sample sizes of 30 and 25 patients achieve $90 \%$ power to detect a difference of $20 \%$ between the null hypotheses of both groups. It was calculated by using Med Calc statistical software assuming area under ROC to be 0.80 , an alpha of 0.05 and power of study $90.0 \%$.

\section{Results}

The participants of this study were attending the obstetrics and gynecology department of our hospital, where an average of a thousand deliveries took place per year. Thirty of them were diagnosed as preeclamptics (group A), and twenty five normal pregnant women (group B) as controls. The demographic characteristics of the study participants are illustrated in (Table 1). There were no statistically significant differences between the two groups for maternal age, parity, gestational age, body mass index (BMI), and mode of delivery. The mean systolic and diastolic blood pressure in preeclamptic women showed a significant increase compared to controls $(153.4 \pm 10.3,98.6 \pm 7.4$ vs 
$108.6 \pm 12.03,72.3 \pm 7.96$ respectively, $\left.\mathrm{p}=0.001^{\star}, 0.001^{\star}\right)($ Table 1$)$.

The results also showed that the mean uric acid, total cholesterol, and triglycerides were significantly higher in group (A) compared to controls $(5.8 \pm 1.0,242.7 \pm 24.8$, $236.8 \pm 27.0$ vs $3.6 \pm 0.54,212 \pm 19.72,178.5 \pm 16.67$ respectively, $\mathrm{p}=0.002^{\star}, 0.003^{*}$, $0.001^{*}$ ) (Table 2 ). On the other hand, there were no statistically significant differences between the two groups regarding urea, creatinine, AST, ALT, and platelets (Table 2). During pregnancy the mean maternal serum leptin levels were significantly higher $41.0 \pm$ $9.78 \mathrm{ng} / \mathrm{ml}$ in preeclamptic group compared to control group $24.6 \pm 3.64 \mathrm{ng} / \mathrm{ml}(\mathrm{p}=$ $0.007^{*}$ ) (Figure 1). Furthermore, the mean maternal serum leptin levels decreased significantly in postpartum period in both groups to $15.3 \pm 3.19$, and $11.2 \pm 2.68 \mathrm{ng} / \mathrm{ml}$ respectively $\left(\mathrm{p}=0.001^{\star}, 0.002^{\star}\right)$ (Figure 2 ).

The clinical characteristics of the newborns are described in (Table 3). There were no statistically significant differences between the neonates in the two groups regarding birth weight, sex, length, head circumference, and Apgar score. It is also evident that,

Table 1. Demographic characteristics of patients in group (A), and (B).

\begin{tabular}{cccc}
\hline & \multicolumn{3}{c}{ Group } \\
\hline Variables & Preeclampsia (A) (n=30) & Control (B) (n=25) & P value \\
\hline Age (years) & $27.5 \pm 2.0$ & $28.6 \pm 1.68$ & $0.068^{\mathrm{a}}$ \\
Gestational age (weeks) & $35.6 \pm 3.0$ & $37.3 \pm 2.98$ & $0.103^{\mathrm{a}}$ \\
Primiparity (\%) & $17(56.7 \%)$ & $10(40.0 \%)$ & $0.165^{\mathrm{b}}$ \\
Body mass index (BMI) & $26.8 \pm 2.3$ & $27.2 \pm 2.27$ & $0.246^{\mathrm{a}}$ \\
Systolic blood pressure (mmHg) & $153.4 \pm 10.3$ & $108.6 \pm 12.03$ & $0.001^{\star a}$ \\
Diastolic blood pressure (mmHg) & $98.6 \pm 7.4$ & $72.3 \pm 7.96$ & $0.001^{\star a}$ \\
Mode of delivery VD/CS & $13 / 17$ & $18 / 7$ & $0.33^{\mathrm{b}}$ \\
\hline
\end{tabular}

Note: Data presented as mean $\pm \mathrm{SD}$; ${ }^{*}$ Significant $(\mathrm{p}<0.05)$; VD: vaginal delivery; CS: cesarean section; ${ }^{\text {aBased }}$ on t-test; ${ }^{\mathrm{b}}$ Based on Chi square test.

Table 2. Biochemical data of patients in group (A), and (B).

\begin{tabular}{cccc}
\hline & \multicolumn{3}{c}{ Group } \\
\hline Variables & Preeclampsia $(\mathrm{A})(\mathbf{n}=\mathbf{3 0})$ & Control (B) $(\mathbf{n}=\mathbf{2 5})$ & P value \\
\hline ALT/SGPT (U/l) & $31.2 \pm 10.7$ & $26.1 \pm 5.98$ & $0.085^{\mathrm{a}}$ \\
AST/SGOT (U/l) & $27.3 \pm 8.78$ & $20.1 \pm 6.78$ & $0.072^{\mathrm{a}}$ \\
Creatinine (mg/dl) & $0.89 \pm 0.19$ & $0.78 \pm 0.16$ & $0.189^{\mathrm{a}}$ \\
Uric acid (mg/dl) & $5.8 \pm 1.0$ & $3.6 \pm 0.54$ & $0.0021^{\star a}$ \\
Platelets & $192,240 \pm 28,645$ & $203,65 \pm 27,116.0$ & $0.098^{\mathrm{a}}$ \\
Urea (mg/dl) & $22.01 \pm 8.46$ & $16.66 \pm 2.97$ & $0.069^{\mathrm{a}}$ \\
Triglycerides (mg/dl) & $236.8 \pm 27.0$ & $178.5 \pm 16.67$ & $0.001^{\star a}$ \\
Total cholesterol (mg/dl) & $242.7 \pm 24.8$ & $212 \pm 19.72$ & $0.0031^{\star a}$ \\
\hline
\end{tabular}

Note: Data presented as mean $\pm \mathrm{SD}$; ${ }^{*}$ Significant $(\mathrm{p}<0.05)$; aBased on $\mathrm{t}$-test. 


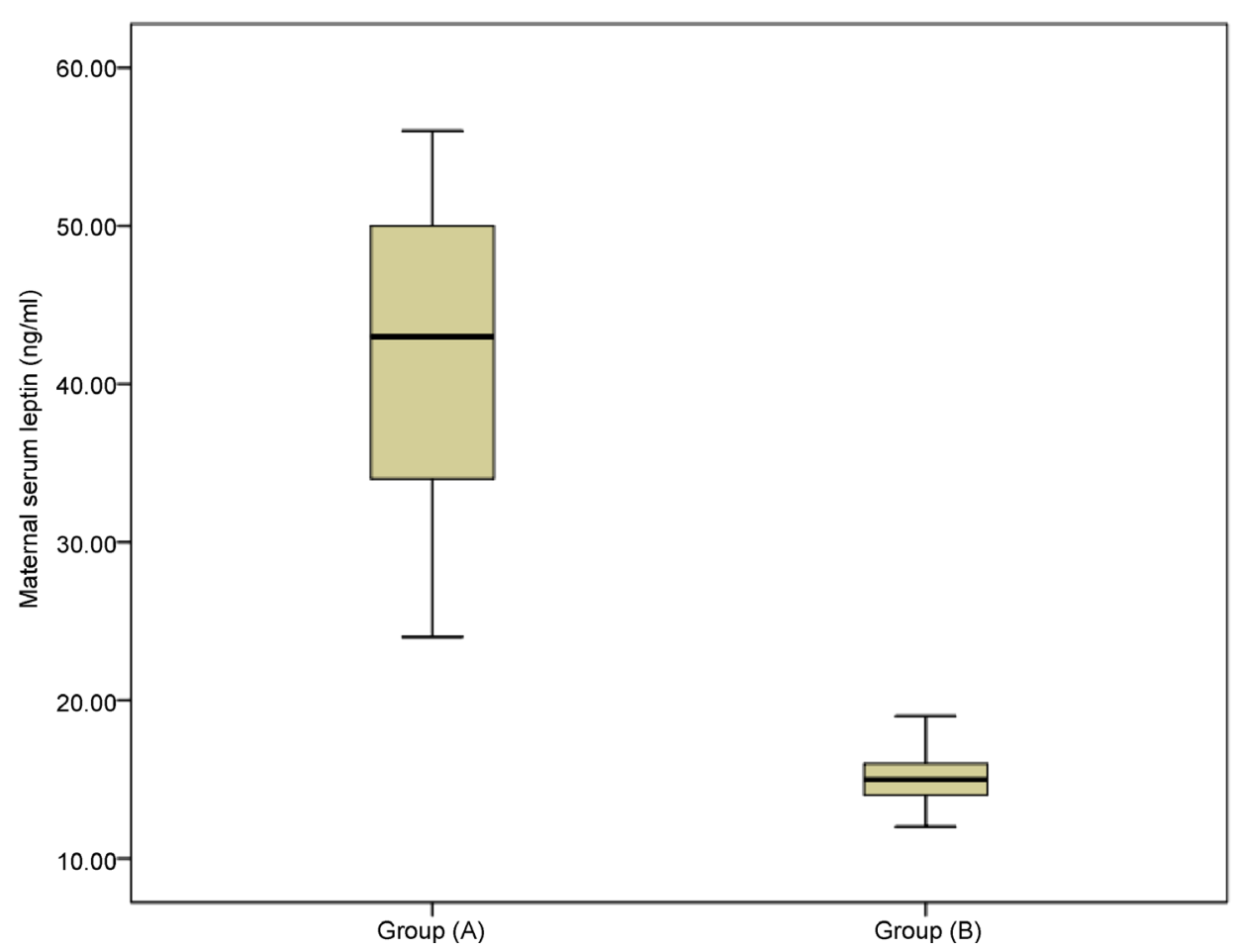

Figure 1. Box and whiskers plot show antepartum maternal serum leptin in group (A), and (B). (Upper whisker: represents the upper $25 \%$ of the distribution. interquartile range box: middle $50 \%$ of the data. Lower whisker represents the lower $25 \%$ of the distribution).

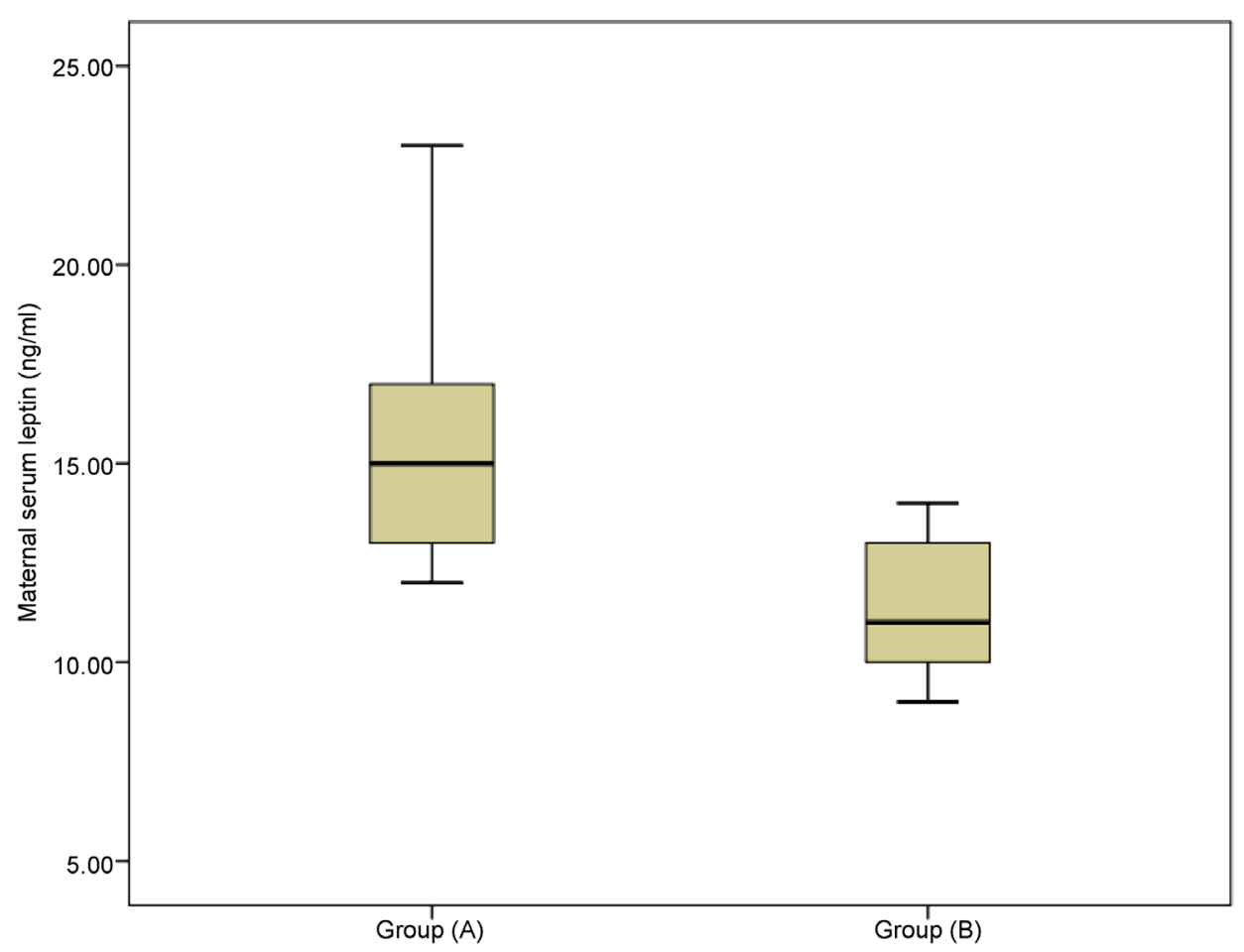

Figure 2. Box and whiskers plot show postpartum maternal serum leptin in group (A), and (B). (Upper whisker: represents the upper $25 \%$ of the distribution. interquartile range box: middle $50 \%$ of the data. Lower whisker represents the lower $25 \%$ of the distribution). 
Table 3. Neonatal demographic and biochemical data in group (A), and (B).

\begin{tabular}{cccc}
\hline & \multicolumn{3}{c}{ Group } \\
\hline Variables & Preeclampsia (A) $(\mathrm{n}=30)$ & Control (B) (n=25) & P value \\
\hline Weight (Grams) & $2850 \pm 264.5$ & $3100 \pm 263.63$ & $0.089^{\mathrm{a}}$ \\
Length (Cm) & $45 \pm 0.9$ & $46 \pm 1.61$ & $0.107^{\mathrm{a}}$ \\
Head Circumference (Cm) & $33 \pm 1.4$ & $35 \pm 0.76$ & $0.071^{\mathrm{a}}$ \\
Sex F/M & $18 / 12$ & $14 / 11$ & $0.764^{\mathrm{b}}$ \\
Leptin (ng/ml) & $10.6 \pm 4.22$ & $12.5 \pm 5.51$ & $0.078^{\mathrm{a}}$ \\
APGAR score & & & \\
1 min & $6.4 \pm 0.65$ & $7.5 \pm 0.61$ & $0.107^{\mathrm{a}}$ \\
5 min & $8.7 \pm 0.52$ & $9.1 \pm 0.32$ & $0.221^{\mathrm{a}}$ \\
\hline
\end{tabular}

Note: Data presented as mean $\pm \mathrm{SD}$; ${ }^{*}$ Significant $(\mathrm{p}<0.05)$; ${ }^{\text {aB }}$ ased on $\mathrm{t}$-test; ${ }^{\mathrm{b}}$ Based on Chi-square test.

no statistically significant difference was detected in umbilical cord leptin between the two groups ( $\mathrm{p}=0.078$ ) in (Table 3 ). In group $(\mathrm{A})$ there were significant positive correlations between maternal serum leptin and diastolic blood pressure $(\mathrm{r}=0.419, \mathrm{p}=$ $\left.0.021^{\star}\right)$, total cholesterol $\left(\mathrm{r}=0.383, \mathrm{p}=0.026^{\star}\right)$, and uric acid $\left(\mathrm{r}=0.424, \mathrm{p}=0.012^{\star}\right)$ compared to controls, while no significant correlations were found between maternal serum leptin and BMI, neonatal birth weight, or cord leptin level in both groups (Table 4).

\section{Discussion}

Leptin, is mainly secreted by the white adipose tissue, and recently proved that this hormone is also secreted by the placental trophoblast cells into the maternal circulation in considerable amounts [2]. Longitudinal studies have documented that leptin levels increase with increasing gestational age [27] [28], or remain stable between the second and third trimester [29]. Mise et al. reported for the first time a significant increase in serum leptin levels in preeclampsia particularly in severely preeclampsia. They documented that, increase in placental leptin messenger RNA expression was proportional to increase in serum leptin levels in preeclampsia, and serum leptin decreased following delivery. This refers to the fact that an increase in serum leptin levels in preeclamptic women is related to placental production [3].

In our study, group (A) and (B) matched well regarding maternal age, parity, BMI, and gestational age. The results of our study showed that, serum leptin level increased with increased blood pressure, as there was a significant increase of serum leptin in preeclamptic women compared to normotensive pregnant women (41.0 \pm 9.78 vs $24.6 \pm$ $3.64 \mathrm{ng} / \mathrm{ml}$ respectively, $\mathrm{p}=0.007^{\star}$ ), which is in agreement with many other previous studies [19] [21] [22], and maternal leptin had a significant positive correlation with diastolic blood pressure in preeclamptic patients $\left(\mathrm{r}=0.419, \mathrm{p}=0.021^{\star}\right)$, but not in healthy pregnant women. Placental ischemia explains rapid increase in leptin concentration during third trimester in preeclampsia. Placental hypoperfusion produces local hypoxia that consequently augments leptin gene expression in the placenta [3]. Also 
Table 4. Correlation between maternal serum leptin and other measured variables in group (A) $\&(B)$.

\begin{tabular}{|c|c|c|c|}
\hline & & Group & \\
\hline Variables & & Preeclampsia $(A)(n=30)$ & Control (B) $(n=25)$ \\
\hline \multirow{2}{*}{ BMI } & $\mathrm{r}$ & 0.112 & 0.241 \\
\hline & $\mathrm{p}$ & 0.365 & 0.245 \\
\hline \multirow{2}{*}{ Systolic blood pressure (SBP) } & $\mathrm{r}$ & 0.153 & -0.080 \\
\hline & $\mathrm{p}$ & 0.421 & 0.704 \\
\hline \multirow{2}{*}{ Diastolic blood pressure (DBP) } & $\mathrm{r}$ & 0.419 & 0.005 \\
\hline & $\mathrm{p}$ & $0.021^{*}$ & 0.981 \\
\hline \multirow{2}{*}{ Creatinine } & $\mathrm{r}$ & 0.199 & 0.017 \\
\hline & $\mathrm{p}$ & 0.292 & 0.936 \\
\hline \multirow{2}{*}{ Uric acid } & $\mathrm{r}$ & 0.424 & 0.032 \\
\hline & $\mathrm{p}$ & $0.012^{*}$ & 0.878 \\
\hline \multirow{2}{*}{ Platelets } & $\mathrm{r}$ & -0.056 & 0.085 \\
\hline & $\mathrm{p}$ & 0.768 & 0.685 \\
\hline \multirow{2}{*}{ Urea } & $\mathrm{r}$ & -0.093 & 0.214 \\
\hline & $\mathrm{p}$ & 0.626 & 0.305 \\
\hline \multirow{2}{*}{ Triglycerides } & $\mathrm{r}$ & -0.328 & 0.162 \\
\hline & $\mathrm{p}$ & 0.077 & 0.439 \\
\hline \multirow{2}{*}{ Total cholesterol } & $\mathrm{r}$ & 0.383 & -0.082 \\
\hline & $\mathrm{p}$ & $0.026^{*}$ & 0.697 \\
\hline \multirow{2}{*}{ Neonatal cord blood leptin } & $\mathrm{r}$ & -0.115 & 0.052 \\
\hline & $\mathrm{p}$ & 0.546 & 0.807 \\
\hline \multirow{2}{*}{ Neonatal weight } & $\mathrm{r}$ & -0.098 & -0.203 \\
\hline & $\mathrm{p}$ & 0.466 & 0.221 \\
\hline \multirow{2}{*}{ Postpartum leptin } & $\mathrm{r}$ & 0.274 & 0.226 \\
\hline & $\mathrm{p}$ & 0.142 & 0.276 \\
\hline
\end{tabular}

r: Correlation; ${ }^{*}$ : Significant correlation.

high leptin levels may be due to the haemoconcentration [30], impaired renal function, and reduced renal clearance in preeclampsia [31].

Some of previous studies documented high circulating leptin level even before the clinical onset of the disease [32]-[34], which might have a prognostic role in preeclamsia. Ning et al. stated that preeclampsia risk increased by $30 \%$ with every $10 \mathrm{ng} / \mathrm{ml}$ increase in leptin concentration [34]. On the contrary, other studies showed decreased or unchanged circulating leptin levels in preeclamptic patients compared to controls [23] [24].

Furthermore, Masuyama et al. reported significant elevation of leptin in early and 
late onset preeclampsia compared to controls [22], while Molvarec et al. found no statistically significant difference in serum leptin concentration between late and early onset preeclampsia and among peeclamptic patients with mild and severe form of the disease [35]. In the current study, it is also revealed that leptin decreased significantly in the early post partum period in group (A) $\left(15.3 \pm 3.19, \mathrm{p}=0.001^{\star}\right)$ and group (B) (11.2 \pm $2.68, \mathrm{p}=0.002^{\star}$ ) which is in line with the results published by Mc Carthy et al. [30], and Saylik et al. [36], but we did not detect any significant difference between both groups in postpartum maternal serum leptin levels.

Leptin has been shown to interfere with lipoprotein and is associated with atherosclerosis [37]. Our findings clarified that, there was a significant increase in serum levels of triglycerides, and total cholesterol in preeclamptic women compared to controls, and leptin is also positively correlated with total cholesterol in preeclamptic patients $(\mathrm{r}=$ $0.383, \mathrm{p}=0.026$ ) but not in controls. These findings are in agreement with results published by Bayhan et al. [38], and Ray et al. [39].

The results of previous studies on correlation between serum leptin and BMI are inconsistent [20] [40] [41], our data showed that, there was no significant correlation between serum leptin and BMI in both groups. This is because in pregnancy the BMI does not accurately show the amount of body fat because the fetus, placenta, amniotic fluid, increased plasma volume and extracellular fluid increase the maternal weight which is prominent in preeclampsia.

Many studies investigated the correlation between maternal serum leptin and baby weight at birth. In our study we did not determine any significant correlation which is in agreement with Tamas et al. [28], and Kolusarı et al. [42], while a significant negative correlation was determined in another study by Saylik et al. [36]. Although maternal serum leptin levels in our study were higher than cord blood levels, but there was no significant correlation between them. This contradicts the results published by Mc Carthy et al. as they found a strong correlation between them in preeclamptic women [30]. Comparing the cord blood leptin level between both groups, there was no statistically significant difference ( $10.6 \pm 4.22$ vs $12.5 \pm 5.51, \mathrm{p}=0.078)$, which was supported previously by Mc Carthy et al. [30]. On the other hand Odegard et al. [43], reported higher cord leptin, and Asnafi et al. [44], reported lower cord leptin in preeclamptic group compared to controls.

\section{Study Limitation}

Our study had some limitations such as; sample collection for this study requires adequate time to be completed based on inclusion and exclusion criteria. In addition, smaller sample size lacking some parameters hence our findings still need more interpretation for further study. This should be addressed by future prospective studies to verify and clarify the relationship between leptin and other uninvestigated parameters.

\section{Conclusion}

In summary, maternal serum leptin is significantly increased in preeclamptic patients 
compared with normal pregnant women independent of BMI. The exact mechanism is not clear, but there is strong evidence that placenta, rather than maternal adipose tissue is responsible for that. In addition, maternal serum leptin levels were found to correlate positively with diastolic blood pressure, uric acid, and total cholesterol, but not correlated with body mass index, cord blood leptin and birth weight. The results of the current study are consistent with pathophysiological roles played by leptin during pregnancy especially in hypoperfused placentae as in preeclampsia which required further studies to explore.

\section{References}

[1] Domali, E. and Messinis, I.E. (2002) Leptin in Pregnancy. Journal of Maternal-Fetal and Neonatal Medicine, 12, 222-230. http://dx.doi.org/10.1080/jmf.12.4.222.230

[2] Masuzaki, H., Ogawa, Y., Sagawa, N., Sagawa, N., Hosoda, K., Matsumot, T., et al. (1997) Non Adipose Tissue Production of Leptin: Leptin as a Novel Placenta-Derived Hormone in Humans. Nature Medicine, 3, 1029-1033. http://dx.doi.org/10.1038/nm0997-1029

[3] Mise, H., Sagawa, N., Matsumoro, N., Yura, S., Nanno, H., Itoh, H., et al. (1998) Augmented Placental Production of Leptin in Pre-Eclampsia: Possible Involvement of Placental Hypoxia. Journal of Clinical Endocrinology and Metabolism, 83, 3225-3229.

[4] Ahima, R.S. and Lier, J.S. (2000) Leptin. Annual Review of Physiology, 2, 413-437. http://dx.doi.org/10.1146/annurev.physiol.62.1.413

[5] Cervero, A., Dominguez, F., Horcajadas, J.A., Quinonero, A., Pellicer, A. and Simon, C. (2006) The Role of the Leptin in Reproduction. Current Opinion in Obstetrics and Gynecology, 18, 297-303. http://dx.doi.org/10.1097/01.gco.0000193004.35287.89

[6] Fantuzzi, G. and Faggioni, R. (2000) Leptin in the Regulation of Immunity, Inflammation, and Hematopoiesis. Journal of Leukocyte Biology, 68, 437-446.

[7] Otero, M., Lago, R., Lago, F., Casanueva, F.F., Dieguez, C., Gómez-Reino, J.J. and Gualillo, O. (2005) Leptin from Fat to Inflammation: Old Questions and New Insights. Federation of European Biochemical Societies Letters, 579, 295-301. http://dx.doi.org/10.1016/j.febslet.2004.11.024

[8] Hauguel-de Mouzon, S., Lepercq, J. and Catalano, P. (2006) The Known and Unknown of Leptin in Pregnancy. American Journal of Obstetrics and Gynecology, 194, 1537-1545. http://dx.doi.org/10.1016/j.ajog.2005.06.064

[9] Hardie, L., Trayhurn, P., Abramovich, D. and Fowler, P. (19997) Circulating Leptin in Women: A Longitudinal Study in the Menstrual Cycle and during Pregnancy. Clinical Endocrinology, 47, 101-106.

[10] Geary, M., Pringle, P.J., Persaud, M., Wilshin, J., Hindmarsh, P.C., Rodeck, C.H. and Brook, C.G. (1999) Leptin Concentrations in Maternal Serum and Cord Blood: Relationship to Maternal Anthropometry and Fetal Growth. British Journal of Obstetrics and Gynecology, 106, 1054-1060. http://dx.doi.org/10.1111/j.1471-0528.1999.tb08113.x

[11] Hassink, S.G., de Lancy, E., Sheslow, D.V., Smith-Kirwin, S.M., O’Connor, D.M., Considine, R.V., et al. (1997) Placental Leptin: An Important New Growth Factor in Intrauterine and Neonatal Development? Pediatrics, 100, E1. http://dx.doi.org/10.1542/peds.100.1.e1

[12] Mise, H., Yura, S., Itoh, H., Nuamah, M.A., Takemura, M., Sagawa, N. and Fujii, S. (2007) The Relationship between Maternal Plasma Leptin Levels and Fetal Growth Restriction. Endocrine Journal, 54, 945-951. http://dx.doi.org/10.1507/endocrj.K06-225 
[13] Briana, D.D. and Malamitsi-Puchner, A. (2009) Reviews: Adipocytokines in Normal and Complicated Pregnancies. Reproductive Sciences, 16, 921-937.

http://dx.doi.org/10.1177/1933719109336614

[14] Sharma, A., Satyam, A. and Sharma, J.B. (2007) Leptin, IL-10 and Inflammatory Markers (TNF-alpha, IL-6 and IL-8) in Pre-Eclamptic, Normotensive Pregnant and Healthy NonPregnant Women. American Journal of Reproductive Immunology, 58, 21-30. http://dx.doi.org/10.1111/j.1600-0897.2007.00486.x

[15] American College of Obstetricians and Gynecologists (2013) Task Force on Hypertension in Pregnancy. Obstetrics and Gynecology, 122, 1122.

[16] Redman, C.W., Sacks, G.P. and Sargent, I.L. (1999) Preeclampsia: An Excessive Maternal Inflammatory Response to Pregnancy. American Journal of Obstetrics \& Gynecology, 180, 499-506. http://dx.doi.org/10.1016/S0002-9378(99)70239-5

[17] Szarka, A., Rigó Jr., J., Lázár, L., Beko, G. and Molvarec, A. (2010) Circulating Cytokines, Chemokines and Adhesion Molecules in Normal Pregnancy and Preeclampsia Determined by Multiplex Suspension Array. BMC Immunology, 11, 59.

http://dx.doi.org/10.1186/1471-2172-11-59

[18] Molvarec, A., Ito, M., Shima, T., Yoneda, S., Toldi, G., Stenczer, B., et al. (2010) Decreased Proportion of Peripheral Blood Vascular Endothelial Growth Factor-Expressing $\mathrm{T}$ and Natural Killer Cells in Preeclampsia. American Journal of Obstetrics \& Gynecology, 203, 567.e1-567.e8. http://dx.doi.org/10.1016/j.ajog.2010.07.019

[19] Haugen, F., Ranheim, T., Harsem, N.K., Lips, E., Staff, A.C. and Drevon, C.A. (2006) Increased Plasma Levels of Adipokines in Preeclampsia: Relationship to Placenta and Adipose Tissue Gene Expression. American Journal of Physiology-Endocrinology and Metabolism, 290, 326-333. http://dx.doi.org/10.1152/ajpendo.00020.2005

[20] Williams, M.A., Havel, P.J., Schwartz, M.W., Leisenring, W.M., King, I.B., Zingheim, R.W., et al. (1999) Pre-Eclampsia Disrupts the Normal Relationship between Serum Leptin Concentrations and Adiposity in Pregnant Women. Paediatric and Perinatal Epidemiology, 13, 190-204. http://dx.doi.org/10.1046/j.1365-3016.1999.00175.x

[21] Adali, E., Yildizhan, R., Kolusari, A., Kurdoglu, M., Bugdayci, G., Sahin, H.G. and Kamaci, M. (2009) Increased Visfatin and Leptin in Pregnancies Complicated by Pre-Eclampsia. The Journal of Maternal-Fetal and Neonatal Medicine, 22, 873-879. http://dx.doi.org/10.1080/14767050902994622

[22] Masuyama, H., Segawa, T., Sumida, Y., Masumoto, A., Inoue, S., Akahori, Y. and Hiramatsu, Y. (2010) Different Profiles of Circulating Angiogenic Factors and Adipocytokines between Early- and Late-Onset Pre-Eclampsia. British Journal of Obstetrics and Gynecology, 117, 314-320. http://dx.doi.org/10.1111/j.1471-0528.2009.02453.x

[23] Laml, T., Preyer, O., Hartman, B.W., Ruecklinger, E., Soeregi, G. and Wagenbichler, P. (2001) Decreased Maternal Serum Leptin in Pregnancies Complicated by Preeclampsia. Journal of the Society for Gynecologic Investigation, 8, 89-89.

http://dx.doi.org/10.1016/S1071-5576(01)00090-9

[24] Martínez-Abundis, E., González-Ortiz, M. and Pascoe-González, S. (2000) Serum Leptin Levels the Severity of Preeclampsia. Archives of Gynecology and Obstetrics, 264, 71-73. http://dx.doi.org/10.1007/s004040000081

[25] Kang, J.H., Song, H., Yoon, J.A., Park, D.Y., Kim, S.H., Lee, K.J., et al. (2011) Preeclampsia Leads to Dysregulation of Various Signaling Pathways in Placenta. Journal of Hypertension, 29, 928-936. http://dx.doi.org/10.1097/HJH.0b013e328344a82c

[26] Catov, J.M., Patrick, T.E., Powers, R.W., Ness, R.B., Harger, G. and Roberts, J.M. (2007) 
Maternal Leptin across Pregnancy in Women with Small-for-Gestational-Age Infants. American Journal of Obstetrics \& Gynecology, 196, 558.e1-558.e8.

http://dx.doi.org/10.1016/j.ajog.2007.01.032

[27] Highman, T.J., Friedman, J.E., Huston, L.P., Wong, W.W. and Catalano, P.M. (1998) Longitudinal Changes in Maternal Serum Leptin Concentrations, Body Composition, and Resting Metabolic Rate in Pregnancy. American Journal of Obstetrics and Gynecology, 178, 1010-1015. http://dx.doi.org/10.1016/S0002-9378(98)70540-X

[28] Tamas, P., Sulyok, E., Szabo, I., Vizer, M., Ertl, T., Rascher, W. and Blum, W.F. (1998) Changes of Maternal Serum Leptin Levels during Pregnancy. Gynecologic and Obstetric Investigation, 46, 169-171. http://dx.doi.org/10.1159/000010026

[29] Sivan, E., Whittaker, P.G., Sinha, D., Homko, C.J., Reece, E.A. and Boden, G. (1998) Leptin in Human Pregnancy: The Relationship with Gestational Hormones. American Journal of Obstetrics and Gynecology, 179, 1128-1132.

http://dx.doi.org/10.1016/S0002-9378(98)70118-8

[30] Mc Carthy, J.F., Misra, D.N. and Roberts, J.M. (1999) Maternal Plasma Leptin Is Increased in Preeclampsia and Positively Correlates with Fetal Cord Concentration. American Journal of Obstetrics and Gynecology, 180, 731-736. http://dx.doi.org/10.1016/S0002-9378(99)70280-2

[31] Sebiha, O., Cemar, T.E., Riza, M. and Kilic, A. (2005) Serum Leptin Levels in Hypertensive Disorder of Pregnancy. European Journal of Obstetrics \& Gynecology and Reproductive Biology, 120, 158-163. http://dx.doi.org/10.1016/j.ejogrb.2004.02.046

[32] Chappell, L.C., Seed, P.T., Briley, A., Kelly, F.J., Hunt, B.J., Charnock-Jones, D.S., et al. (2002) A Longitudinal Study of Biochemical Variables in Women at Risk of Preeclampsia. American Journal of Obstetrics and Gynecology, 187, 127-136. http://dx.doi.org/10.1067/mob.2002.122969

[33] Samolis, S., Papastefanou, I., Panagopoulos, P., Galazios, G., Kouskoukis, A. and Maroulis, G. (2010) Relation between First Trimester Maternal Serum Leptin Levels and Body Mass Index in Normotensive and Pre-Eclamptic Pregnancies Role of Leptin as a Marker of PreEclampsia: A Prospective Case-Control Study. Gynecological Endocrinology, 26, 338-343. http://dx.doi.org/10.3109/09513590903511463

[34] Ning, Y., Williams, M.A., Muy-Rivera, M., Leisenring, W.M. and Luthy, D.A. (2004) Relationship of Maternal Plasma Leptin and Risk of Pre-Eclampsia: A Prospective Study. The Journal of Maternal-Fetal and Neonatal Medicine, 15, 186-192. http://dx.doi.org/10.1080/14767050410001668293

[35] Molvarec, A., Szarka, A., Walentin, S., Beko, G., Karádi, I., Prohászka, Z. and Rigó Jr., J. (2011) Serum Leptin Levels in Relation to Circulating Cytokines, Chemokines, Adhesion Molecules and Angiogenic Factors in Normal Pregnancy and Preeclampsia. Reproductive Biology and Endocrinology, 9, 124. http://dx.doi.org/10.1186/1477-7827-9-124

[36] Saylik, S.A., Alkis, I., Bayram, N., Tuna, V., Imamoglu, N. and Ceylan, Y. (2013) Maternal Serum Leptin Levels in Severe Preeclamptic Pregnant Women in Early Postpartum Stage. International Journal of Obstetrics and Gynecology, 2, 10-14.

[37] Kastarinen, H., Kesaniemi, Y.A. and Ukkola, O. (2009) Leptin and Lipid Metabolism in Chronic Kidney Failure. Scandinavian Journal of Clinical and Laboratory Investigation, 69, 401-408. http://dx.doi.org/10.1080/00365510802706645

[38] Bayhan, G., Kocyigit, Y., Atamer, A., Atamer, Y. and Akkus, Z. (2005) Potential Atherogenic Roles of Lipids, Lipoprotein(a) and Lipid Peroxidation in Pre-Eclampsia. Gynecological Endocrinology, 21, 1-6. 
[39] Ray, J.G., Diamond, P., Singh, G. and Bell, C.M. (2006) Brief Overview of Maternal Triglycerides as a Risk Factor for Pre-Eclampsia. British Journal of Obstetrics and Gynecology, 113, 379-386. http://dx.doi.org/10.1111/j.1471-0528.2006.00889.x

[40] Kafulafula, G.E., Moodley, J., Ojwang, P.S. and Kagoro, H. (2002) Leptin and Pre-Eclampsia in Black African Parturients. British Journal of Obstetrics and Gynecology, 109, 1256-1261. http://dx.doi.org/10.1046/j.1471-0528.2002.02043.x

[41] Hendler, I., Blackwell, S.C., Mehta, S.H., Whitty, J.E., Russell, E., Sorokin, Y. and Cotton, D.B. (2005) The Levels of Leptin, Adiponectin, and Resistin in Normal Weight, Overweight, and Obese Pregnant Women with and without Preeclampsia. American Journal of Obstetrics and Gynecology, 193, 979-983. http://dx.doi.org/10.1016/j.ajog.2005.06.041

[42] Kolusarı, A., Kurdoglu, M., Yıldızhan, R., Adalı, E., Cebi, A., Demir, H. and Yoruk, H. (2008) Catalase Activity, Serum Trace Element and Heavy Metal Concentrations, and Vitamin A, D, and E Levels in Pre-Eclampsia. Journal of International Medical Research, 36, 1335-1341. http://dx.doi.org/10.1177/147323000803600622

[43] Odegard, R.A., Vatten, L.J., Nilsen, S.T., Salvesen, K.A. and Austgulen, R. (2002) Umbilical Cord Plasma Leptin Is Increased in Preeclampsia. American Journal of Obstetrics and Gynecology, 186, 427-432. http://dx.doi.org/10.1067/mob.2002.120486

[44] Asnafi, N., Sharbatdaran, M. and Karimollah, H. (2011) Comparison of Maternal and Neonatal Serum Leptin Levels in Preeclampsia and Normal Pregnancy. Iranian Journal of Reproductive Medicine, 9, 131-134.

\section{Submit or recommend next manuscript to SCIRP and we will provide best service} for you:

Accepting pre-submission inquiries through Email, Facebook, LinkedIn, Twitter, etc. A wide selection of journals (inclusive of 9 subjects, more than 200 journals)

Providing 24-hour high-quality service

User-friendly online submission system

Fair and swift peer-review system

Efficient typesetting and proofreading procedure

Display of the result of downloads and visits, as well as the number of cited articles

Maximum dissemination of your research work

Submit your manuscript at: http://papersubmission.scirp.org/ 